\title{
Somatotroph Adenoma
}

National Cancer Institute

\section{Source}

National Cancer Institute. Somatotroph Adenoma. NCI Thesaurus. Code C7461.

An adenoma of the anterior lobe of the pituitary gland that produces growth hormone.

The vast majority of cases are hormonally functioning and are associated with either gigantism or acromegaly. 